\title{
Protective effects of Zizyphus oxyphyla on liver and kidney related serum biomarkers in $\left(\mathrm{CCl}_{4}\right)$ intoxicate rabbits
}

\author{
Efeitos protetores de Zizyphus oxyphyla em biomarcadores de soro relacionados ao \\ fígado e rim em $\left(\mathrm{CCl}_{4}\right)$ intoxicam rabbtis
}

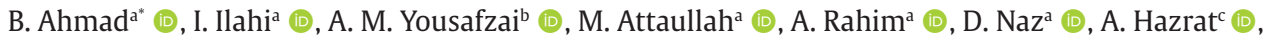 \\ G. E-S. Batiha ${ }^{d}$ (I), M. A. Nassan ${ }^{\mathrm{e}}$ (D) and A. A. K. Khalil ${ }^{\text {(D) }}$ \\ a University of Malakand, Department of Zoology, Khyber Pakhtunkhwa, Pakistan \\ ${ }^{\mathrm{b}}$ Islamia College, Department of Zoology, Peshawar, Pakistan \\ 'University of Malakand, Departments of Botany, Khyber Pakhtunkhwa, Pakistan \\ d Damanhour University, Faculty of Veterinary Medicine, Department of Pharmacology and Therapeutics, Damanhour, AlBeheira, Egypt \\ e Taif University, Turabah University College, Department of Clinical Laboratory Sciences, Taif, Saudi Arabia \\ ${ }^{\mathrm{f}}$ National University of Medical Sciences, Department of Biological Sciences, Rawalpindi, Pakistan
}

\begin{abstract}
The study was aimed to evaluate the therapeutic effects of Zizyphus oxyphyla leaves methanolic (ZOX-LME), on serum liver, kidney and hematology along with other serum parameters in Carbon tetrachloride $\left(\mathrm{CCl}_{4}\right)$ intoxicated rabbits. Experimental animals were divided into five groups, six rabbits in each. These were: group NC (normal control), group, TC (toxic control) and group ST i.e. silymarine administered group at dose rate (50) $\mathrm{mg} / \mathrm{kg}$ body weight (BW). Group ET1 and group ET2 treated with (ZOX-LME) at dose $200 \mathrm{mg} / \mathrm{kg} \mathrm{BW}$ and $400 \mathrm{mg} / \mathrm{kg} \mathrm{BW}$. CCl ${ }_{4}$ administration caused significant $(\mathrm{P}>0.05)$ impairment in serum liver enzymes, blood factors and other serum indices. Treatment with $($ ZOX-LME) significantly $(P<0.05)$ reduced and normalized the levels of serum alanine transaminase (ALT) aspartate transaminase (AST) and alkaline phosphatase (ALP) and hematological indices. Also significant $(\mathrm{P}<0.05)$ reduction was observed in creatinine, urea, uric acid, blood urea nitrogen (BUN),

and albumin and glucose concentrations. The altered levels of lipid profile and serum electrolytes $(\mathrm{Ca}, \mathrm{Mg}, \mathrm{Cl}$, $\mathrm{Na}, \mathrm{K}$, and $\mathrm{P}$ ) were significantly $(\mathrm{P}<0.05)$ change toward normal levels with (ZOX-LME) feeding. In addition (ZOX-LME) ingestion caused significant improvement in GSH, GST and CAT levels, while reducing the TBARS levels, exhibited antioxidant capacity. Also (ZOX-LME) showed increase inhibition against percent scavenging of 2, 2-diphenile-1-picrylehydrazyle (DPPH) free radical. Significant $(\mathrm{P}<0.05)$ normalizing effects were observed with high dose $400 \mathrm{mg} / \mathrm{kg}$ BW of (ZOX-LME and were equivalent to silymarine administered groups. The histological study of liver supported the hepatoprotective and renal curative activity of (ZOX-LME).
\end{abstract}

Keywords: methanol extract, hematological parameters, serum levels, 2, 2-diphenile-1-picrylehydrazyle (DPPH), hepatoprotective, (ZOX-LME).

\begin{abstract}
Resumo
O estudo teve como objetivo avaliar os efeitos terapêuticos das folhas metanólicas de Zizyphus oxyphyla (ZOX-LME) no fígado, rim e hematologia séricos, juntamente com outros parâmetros séricos em coelhos intoxicados com tetracloreto de carbono $\left(\mathrm{CCl}_{4}\right)$. Os animais experimentais foram divididos em cinco grupos, seis coelhos em cada. Estes foram: grupo NC (controle normal), grupo TC (controle tóxico) e grupo ST, isto é, grupo administrado com silimarina na taxa de dose (50) $\mathrm{mg} / \mathrm{kg}$ de peso corporal (PC). Grupo ET1 e grupo ET2 tratado com (ZOX-LME) na dose de $200 \mathrm{mg} / \mathrm{kg}$ de peso corporal e $400 \mathrm{mg} / \mathrm{kg}$ de peso corporal. A administração de $\mathrm{CCl}_{4}$ causou prejuízo significativo $(P>0,05)$ nas enzimas hepáticas séricas, fatores sanguíneos e outros índices séricos. $O$ tratamento com (ZOX-LME) reduziu significativamente $(\mathrm{P}<0,05)$ e normalizou os níveis de alanina transaminase (ALT), aspartato transaminase (AST) e fosfatase alcalina (ALP) e os índices hematológicos. Também foi observada redução significativa $(\mathrm{P}<0,05)$ nas concentrações de creatinina, ureia, ácido úrico, nitrogênio ureico no sangue (BUN), albumina e glicose. Os níveis alterados de perfil lipídico e eletrólitos séricos ( $\mathrm{Ca}, \mathrm{Mg}, \mathrm{Cl}, \mathrm{Na}, \mathrm{K}$ e $\mathrm{P}$ ) foram significativamente $(\mathrm{P}<0,05)$ mudando em direção aos níveis normais com a alimentação (ZOX-LME). Além disso, a ingestão de (ZOX-LME) causou melhora significativa nos níveis de GSH, GST e CAT, enquanto reduzia os níveis de TBARS, exibindo capacidade antioxidante. Também (ZOX-LME) mostrou inibição aumentada contra a eliminação percentual do radical livre 2, 2-difenila-1-picrilehidrazila (DPPH). Efeitos de normalização significativos $(\mathrm{P}<0,05)$ foram observados com
\end{abstract}

*e-mail: basheer.icup@gmail.com

Received: December 26, 2020 - Accepted: April 13, 2021 
altas doses de $400 \mathrm{mg}$ / $\mathrm{kg}$ de peso corporal de (ZOX-LME) e foram equivalentes aos grupos administrados com silimarina. $\mathrm{O}$ estudo histológico do fígado confirmou a atividade hepatoprotetora e curativa renal de (ZOX-LME).

Palavras-chave: extrato de metanol, parâmetros hematológicos, níveis séricos, 2, 2-difenila-1-picrilehidrazila (DPPH), hepatoprotetor, (ZOX-LME).

\section{Introduction}

The liver is a vital organ responsible for various metabolic functions and clearance and transformation of drugs and toxins from the blood and regulate immune responses (Yan et al., 2014).

Kidney is also important homeostatic organ (Mitrakou, 2011). Thus both are exposed to toxic injury. Toxicity in animals may be either through the production of secondary metabolites or by the other organisms, i.e., microbes, plants or other animals hosted by them (Luckner, 2013). More than thousand drugs of the current pharmaceutical era have been shown to cause hepato and renal toxicity with diverse clinical appearances (Björnsson, 2016). Hepatic and renal injury is related always with cellular necrosis; decrease in tissue lipid peroxidation (Contreras-Zentella and Hernández-Muñoz, 2016). More over serum levels of many biochemical markers like alanine amino transaminase (ALT), aspartate amino transaminase (AST), serum glutamic oxalo acetic transaminase (SGOT), serum glutamic pyruvic transaminase (SGPT), total cholesterol, and total bilirubin (TB) are evaluated along with serum electrolyte, urea, uric acid and creatinine imbalances are assessed (Olaniyan and Ateni, 2018).

Different aspects of liver injury during hepatotoxicity may include hepatitis (Wang et al., 2013); granuloma (Kamal et al., 2012); vascular lesions (Rubbia-Brandt et al., 2010). The major effect of hepatotoxicity is jaundice which is caused due to bilirubin accumulation in the extra cellular fluid, causing weakness, severe fatigue, dark urine and light colored stool (Frenzel and Teschke, 2016).

A number of chemical toxicants have also been reported for toxicity in animals and humans. Carbon tetrachloride $\left(\mathrm{CCl}_{4}\right)$ is one of the toxic agent (Danladi et al., 2013) The level of tissue injury is related to the amount of dose and period of exposure to carbon tetrachloride (Abdel-Moneim et al., 2015). Its mechanism of toxicity is based on lipid membrane peroxidation and generation of trichlomethyl radical $(\cdot \mathrm{CCl} 3)$, causing severe cell injury (Tan et al., 2016).

Many investigators have given the reports about plants, that having phenolic compounds such as tannins, flavonoids, procyanidins, anthocyanins and phenolic acids have liver, heart and nephroprotective activities (Oliboni et al., 2011) Several studies have revealed that the plant extracts possessing antioxidant activity that defend carbon tetrachloride $\mathrm{CCl}_{4}$ induced hepatotoxicity by preventing peroxidation of lipid and increasing antioxidant Enzyme activity (El-Haskoury et al., 2018; Mahmoodzadeh et al., 2017). In vitro anti-oxidant activates are carried out by using different free radicals including DPPH, Hydrogen peroxide, super oxide, Nitric oxide, trichloromethyl $\left(\mathrm{CCl}_{3}\right)$ (Leamklang, 2018) DPPH (2, 2-diphenyl-1- picrylhydrazyl) is a familiar "scavenger") for other radicals.(Adegoke et al., 2012). During the present study the Zizyphus Oxyphyla plant was selected. Commonly found in Pakistan, Africa, Australia, and tropical America (Kaleem, 2011). Traditionally in the rural areas the root of Zizyphus oxyphyla are dried, boiled in water, filtered, and used in the treatment of liver disorder, especially for jaundice (Ijaz et al., 2016). It has also been found that some species have antiulcer genic activity (Sharifi-Rad et al., 2018). Moreover the study was aimed to investigate the effect of methanolic extract of Zizyphus oxyphyla leave's (ZOX-LME) on liver and renal related serum parameters, hematological indices and lipid profile. In addition and serum electrolytes and serum antioxidant biomarkers like, glutathione (GSH), (GST) superoxide dismutase (SOD) and thiobarbituric acid reactive substances (TBARS) were studied. Furthermore in-vitro antioxidant capacity based on (DPPH) scavenging assay was performed and permanent slides of liver and kidney sections were prepared for histopathological findings.

\section{Materials and Methods}

\subsection{Study area, plant material and extraction}

The Zizyphus oxyphyla plant was collected from the Mountain of village Shamozai, District Swat. K.P.K Pakistan in the year 2019. Following authentication was made from a voucher specimen deposited in Herbarium, Botany Department University of Malakand. The shade dried leaves were ground with (ZK-115, Japan) and obtain powder of about 830 gram was soaked in $1500 \mathrm{~mL}$ of $100 \%$ methanol and crude extract @ (ZOX-LME) of red black color was obtained after processing.

\subsection{Animals and study regime}

Forty adult domestic male rabbits (Oryctoagus cuniculus), weighing round about 1000-1350 gram and 6-7 month old were procured from the local market. For acclimation, the animals were for 14 days, before start of the experimental work. All animal procedures are in accordance with the recommendations of the research animals committee for care and use of Griffin and Locke (2016). During the experimentation, a total of 40 adult male rabbits were divided into five groups, comprising of eight animals in each group.

Group NC: Normal control group (10 mL/kg body weight (BW) of normal saline orally;

Group TC: Toxic Control group (10 mL/kg body weight of $\mathrm{CCl}_{4}(50 \% \mathrm{v} / \mathrm{v}$ in olive oil rally;

Group ST: Standard Control group (Silymarin @ 50 mg/kg BW dissolved in $10 \mathrm{~mL}$ mineral water each day oral after intoxication;

Group ET1: (ZOX-LME) @ 200 mg/kg BW, each day oral after intoxication; 
Group ET2: (ZOX-LME) @ 400 mg/kg BW, each day oral after intoxication.

\subsection{Acute toxicity test}

The acute toxicity study was carried out for the (ZOX-LME) of different doses i.e. 1000, 1500 and 2000 in mg per kg body weight. Acute toxicity was determined according to the Organization for economic co-operation and development (OECD) guideline number, 420 (OECD, 2001). During this test, the (ZOX-LME) was assigned safe up to highest dose (2000 mg/kg BW) as no mortality was caused.

\subsection{Hematological, biochemical and histopathological study}

All animals were dissected on the last day of experimentation. Blood ( $3.5 \mathrm{~mL}$ ) was collected in Ethylene Diamine Tetra-acetic Acid (EDTA)-coated tubes (K2-EDTA tubes) and into sterile coagulant tubes and were subjected for hematological and biochemical analysis i.e. alanine transaminase (ALT), aspartate transaminase (AST) and alkaline phosphatase (ALP). Serum Glucose, urea, uric acid, creatinine, BUN and albumin were estimated, along with total serum cholesterol, HDL, LDL, VLDL and triglyceride were determined. Liver from each animal was rapidly excised after dissection. $0.5 \mathrm{~g}$ liver tissue was homogenized in $5 \mathrm{~mL} 0.9 \% \mathrm{Na} \mathrm{Cl}(10 \% \mathrm{w} / \mathrm{v})$ using a Teflon homogenizer (Glass-Col, Terre Haute, USA).

\subsection{Serum oxidative biomarkers assay}

Serum catalase (CAT), glutathione-S-transferase (GST) and (GSH) also Thiobarbituric acid reactive substances (TBARS) were determined according to the manufacturer's instructions of assay kits (Biodiagnostic Company, Egypt).

\subsection{DPPH radical scavenging activity}

The in vitro antioxidant activities of (ZOX-LME) was evaluated on the basis of (DPPH) scavenging assay by using earlier procedures (Koksal et al., 2011). The concentration of solutions prepared for the activity were expressed as parts per million (ppm), equal to $\mathrm{mg} / \mathrm{L}$. A $25 \mathrm{~mL}$ stock solution of 500 ppm of (ZOX-LME) was prepared in methanol. From the stock solution; a $5 \mathrm{~mL}$ solution each of 20,40 , 80,100 and 200 ppm was prepared in separate test tubes. Each concentration was taken in triplicate. The same procedure was repeated for ascorbic acid which was used as standard using 1700 Shimadzu Japan) at $517 \mathrm{~nm}$ for absorbance. The following Formula 1 was used:

Percent radical scavenging activity $=(A c-A s / A c) \times 100)(1)$

where 'Ac' is the absorbance of control, 'As' is the absorbance of sample.

\subsection{Statistical analysis}

The data (expressed as mean \pm SE) were analyzed by one way ANOVA and "Tukey test" using SPSS software. Values of $\mathrm{p}<0.05$ were considered to be statistically significant.

\section{Result}

The results of acute oral toxicity showed no signs and symptoms of illness and mortality was seen with (ZOX-LME) administration up to $2000 \mathrm{mg} / \mathrm{kg} \mathrm{BW).} \mathrm{The} \mathrm{effect}$ of (ZOX-LME) on the values of ALT, AST, ALP, RBCs, WBCs, platelets and haemoglobin (HB) are presented in Table 1. The results indicate that $\mathrm{CCl}_{4}$ administration significantly $(\mathrm{P}<0.05)$ increased the serum levels of ALT, AST and ALP as compare with control group A. After treatment with (ZOX-LME) at high dose (400 mg/kg BW), significantly $(\mathrm{P}<0.05)$ lowered the concentration of ALT, AST and ALP ( group $=$ ET2) and caused a consequent normalization . The mean values of RBCs WBCs, Platelets and hemoglobin $(\mathrm{Hb})$ showed in Table 1 . A significant $(\mathrm{P}<0.05)$ reduction in the activities of RBC, WBC, Platelets and hemoglobin $\mathrm{Hb}$ ) were observed in rabbits that received $\mathrm{CCl}_{4}$ alone (group TC), when compared to normal control rabbits. The administration of (ZOX-LME) at $200 \mathrm{mg} / \mathrm{kg}$ BW, caused no-significant ( $p>0.05$ ) reduction in the concentration of heamatological parameters while at dose rate $400 \mathrm{mg} / \mathrm{kg}$ body weight significantly reduced the elevated level of

Table 1. Shows liver function enzymes and heamatological indices in the experimental animal groups treated with $\mathrm{CCl}_{4}$, silymarine and (ZOX-RBM), extract.

\begin{tabular}{cccccc}
\hline \multirow{2}{*}{ Parameters } & \multicolumn{5}{c}{ Experimental groups } \\
\cline { 2 - 6 } & \multicolumn{1}{c}{ NC } & \multicolumn{1}{c}{ TC } & ST & ET1 & ET2 \\
\hline Serum ALT $(\mathrm{IU} / \mathrm{L})$ & $32.08 \pm 2.8 \mathrm{a}$ & $88.61 \pm 6.7 \mathrm{~b}$ & $33.85 \pm 4.2 \mathrm{a}$ & $68.84 \pm 3.8 \mathrm{c}$ & $37.65 \pm 3.6 \mathrm{a}$ \\
Serum AST $(\mathrm{IU} / \mathrm{L})$ & $44.55 \pm 1.6 \mathrm{a}$ & $102.7 \pm 6.5 \mathrm{~b}$ & $48.15 \pm 1.4 \mathrm{a}$ & $88.89 \pm 3.7 \mathrm{c}$ & $49.25 \pm 1.0 \mathrm{a}$ \\
Serum ALP $(\mathrm{IU} / \mathrm{L})$ & $58.27 \pm 2.4 \mathrm{a}$ & $134.8 \pm 2.2 \mathrm{~b}$ & $59.44 \pm 6.7 \mathrm{a}$ & $113.7 \pm 3.8 \mathrm{c}$ & $63.20 \pm 2.9 \mathrm{a}$ \\
RBC $\times 10^{6} / \mu \mathrm{L}$ & $5.7 \pm 0.09 \mathrm{a}$ & $3.2 \pm 0.09 \mathrm{~b}$ & $5.4 \pm 0.04 \mathrm{a}$ & $4.2 \pm 0.13 \mathrm{c}$ & $5.4 \pm 0.04 \mathrm{ac}$ \\
WBC $\times 10^{3} / \mu \mathrm{L}$ & $6.2 \pm 0.34 \mathrm{a}$ & $3.97 \pm 0.08 \mathrm{~b}$ & $5.96 \pm 0.25 \mathrm{a}$ & $4.02 \pm 0.11 \mathrm{c}$ & $5.73 \pm 0.0 \mathrm{a}$ \\
Platelets $\times 10^{3} / \mu \mathrm{L}$ & $139 \pm 5.64 \mathrm{a}$ & $241 \pm 5.49 \mathrm{~b}$ & $147 \pm 1.19 \mathrm{a}$ & $198 \pm 3.8 \mathrm{c}$ & $154 \pm 3.85 \mathrm{a}$ \\
Hemoglobin $\mathrm{g} / \mathrm{dL}$ & $11.47 \pm 0.45 \mathrm{a}$ & $7.87 \pm 0.63 \mathrm{~b}$ & $11.22 \pm 0.51 \mathrm{a}$ & $9.98 \pm 0.27 \mathrm{c}$ & $10 \pm 1.41 \mathrm{ac}$ \\
\hline
\end{tabular}

$\mathrm{NC}=$ Normal Control; TC = Toxic Control; ST = Silymarine Control; ET1 = Extract (ZOX-LME) $200 \mathrm{mg} / \mathrm{kg}$ BW; ET2 = Extract (ZOX-LME) 400 mg/kg BW. Same alphabets in a row shows no significant difference $(\mathrm{P}<0.05)$ while the different alphabets in the same row show significant difference $(\mathrm{P}<0.05)$ among the mean of the parameters. 
hemoglobin, RBC,WBC and platelets when compared to toxic control animals. Animals feed with silymarine significantly $(p>0.05)$ normalized the values of liver enzymes and hemoglobin, RBC and Platelets respectively.

A statistically significantly $(\mathrm{P}<0.05)$ elevation was observed in the creatinine, urea, uric acid, blood urea nitrogen, albumin and glucose levels, when the animals were exposed to $\mathrm{CCl}_{4}$ (Table 2). Likewise serum electrolytes such as $\mathrm{Ca}, \mathrm{Mg}, \mathrm{Cl}, \mathrm{Na}, \mathrm{K}$ and $\mathrm{P}$ concentration were elevated. No significant reduction had occurred with the feeding of (ZOX-LME) at $200 \mathrm{mg} / \mathrm{kg}$ BW. Though a highly significant $(P<0.05)$, reduction in the levels of urea, uric acid, creatinine, blood urea nitrogen, albumin, glucose and serum electrolytes were noted with the intake of (ZOX-LME) (400 mg/ kg.BW) and silymarine (50 mg/kg $\mathrm{BW})$ respectively. The levels of total lipid, cholesterol, triglycerides, LDL and VLDL were significantly $(\mathrm{P}<0.05)$ elevated and HDL was reduced in the in animals feed with $\mathrm{CCl}_{4}$ shown in Table 3.
The ingestion of (ZOX-LME) at dose ( $400 \mathrm{mg} / \mathrm{kg} \mathrm{BW})$ showed significant $(P<0.05)$ therapeutic effect while, $200 \mathrm{mg} / \mathrm{kg}$ BW, (ZOX-LME) revealed non-significant effect on the levels of lipid profile when compared to toxic control animals.

Table 4 revealed that carbon tetrachloride $\mathrm{CCl}_{4}$ induced hepatic and renal toxicity, as significant $(\mathrm{p}<0.05)$ reduction was observed in serum glutathione GSH, GST and SOD, while (TBARS) levels was elevated when compared with control animals. The (ZOX-LME) (200 mg/kg BW) showed a mild curative effect but not significant effect on serum antioxidant biomarkers, while the (ZOX-LME) at dose rate $400 \mathrm{mg} / \mathrm{kg} \mathrm{BW}$, significantly ( $\mathrm{p}<0.05$ ) improved the GSH, GST and SOD levels and reduced the (TBARS) toward normal value when compared to normal control and toxic control animals respectively. The results of high dose extract animals were comparable with silymarine administered animals. The results of high dose (ZOXLME)) were comparable with that of silymarin (50 mg/

Table 2. Shows Kidney function enzymes, glucose and serum electrolytes level in the experimental animal groups treated with $\mathrm{CCl}_{4}$, silymarine and (ZOX-LME), extract.

\begin{tabular}{cccccc}
\hline \multirow{2}{*}{$\begin{array}{c}\text { Parameters }(\mathbf{m g} / \\
\text { dl) }\end{array}$} & \multicolumn{5}{c}{ Experimental groups } \\
\cline { 2 - 6 } NC & TC & ST & ET1 & ET2 \\
\hline Creatinine & $0.28 \pm 0.08 \mathrm{a}$ & $0.97 \pm 0.10 \mathrm{~b}$ & $0.37 \pm 0.8 \mathrm{a}$ & $0.67 \pm 0.04 \mathrm{c}$ & $0.39 \pm 0.09 \mathrm{a}$ \\
Urea & $27.08 \pm 1.2 \mathrm{a}$ & $56.76 \pm 0.7 \mathrm{~b}$ & $30.31 \pm 0.65 \mathrm{a}$ & $46.48 \pm 2.6 \mathrm{c}$ & $32.98 \pm 1.7 \mathrm{a}$ \\
Uric acid & $0.44 \pm 0.02 \mathrm{a}$ & $0.83 \pm 0.09 \mathrm{~b}$ & $0.47 \pm 0.02 \mathrm{a}$ & $0.66 \pm 0.00 \mathrm{c}$ & $0.54 \pm 0.02 \mathrm{ac}$ \\
BUN & $14.09 \pm 0.60 \mathrm{a}$ & $26.81 \pm 1.30 \mathrm{~b}$ & $16.45 \pm 1.75 \mathrm{a}$ & $20.95 \pm 0.98 \mathrm{c}$ & $17.23 \pm 0.73 \mathrm{a}$ \\
Albumin & $2.74 \pm 0.19 \mathrm{a}$ & $5.51 \pm 0.21 \mathrm{~b}$ & $2.93 \pm 0.06 \mathrm{a}$ & $4.11 \pm 0.25 \mathrm{c}$ & $2.83 \pm 0.41 \mathrm{a}$ \\
Glucose & $95 \pm 3.60 \mathrm{a}$ & $137 \pm 4.62 \mathrm{~b}$ & $104 \pm 4.66 \mathrm{a}$ & $113 \pm 4.33 \mathrm{c}$ & $106 \pm 3.36 \mathrm{ac}$ \\
$\mathrm{Ca}(\mathrm{mmol} / \mathrm{L})$ & $4.97 \pm 0.25 \mathrm{a}$ & $9.06 \pm 0.35 \mathrm{~b}$ & $4.90 \pm 0.23 \mathrm{a}$ & $6.19 \pm 0.14 \mathrm{c}$ & $5.16 \pm 0.30 \mathrm{ac}$ \\
$\mathrm{Mg}(\mathrm{mmol} / \mathrm{L})$ & $0.42 \pm 0.01 \mathrm{a}$ & $0.72 \pm 0.04 \mathrm{~b}$ & $0.46 \pm 0.01 \mathrm{a}$ & $0.54 \pm 0.01 \mathrm{c}$ & $0.48 \pm 0.02 \mathrm{a}$ \\
$\mathrm{Cl}(\mathrm{mmol} / \mathrm{L})$ & $99.4 \pm 2.84 \mathrm{a}$ & $120.6 \pm 1.8 \mathrm{~b}$ & $101.7 \pm 2.3 \mathrm{a}$ & $109.9 \pm 2.3 \mathrm{c}$ & $105.4 \pm 1.6 \mathrm{ac}$ \\
$\mathrm{Na}(\mathrm{mmol} / \mathrm{L})$ & $134.4 \pm 1.5 \mathrm{a}$ & $159.7 \pm 2.7 \mathrm{~b}$ & $136.1 \pm 0.75 \mathrm{a}$ & $145.1 \pm 1.16 \mathrm{c}$ & $137.5 \pm 0.36 \mathrm{a}$ \\
$\mathrm{K}(\mathrm{mmol} / \mathrm{L})$ & $5.30 \pm 0.18 \mathrm{a}$ & $7.62 \pm 0.34 \mathrm{~b}$ & $5.56 \pm 0.15 \mathrm{a}$ & $6.33 \pm 0.24 \mathrm{c}$ & $5.58 \pm 0.38 \mathrm{a}$ \\
$\mathrm{P}(\mathrm{mmol} / \mathrm{L})$ & $1.24 \pm 0.01 \mathrm{a}$ & $1.59 \pm 0.04 \mathrm{~b}$ & $1.27 \pm 0.02 \mathrm{a}$ & $1.38 \pm 0.00 \mathrm{c}$ & $1.29 \pm 0.00 \mathrm{a}$ \\
\hline
\end{tabular}

NC = Normal Control; TC = Toxic Control; ST = Silymarine Control; ET1 = Extract (ZOX-LME) $200 \mathrm{mg} / \mathrm{kg}$ BW; ET2 = Extract (ZOX-LME) $400 \mathrm{mg} / \mathrm{kg}$ $\mathrm{BW}$. Same alphabets in a row shows no significant difference $(\mathrm{P}<0.05)$ while the different alphabets in the same row show significant difference $(\mathrm{P}<0.05)$ among the mean of the parameters.

Table 3. Shows $(\mathrm{M} \pm \mathrm{SD})$ values of lipid profile of the experimental animal groups treated with $\mathrm{CCl}_{4}$, silymarine and (ZOX-LME), extract.

\begin{tabular}{|c|c|c|c|c|c|}
\hline \multirow{2}{*}{ Lipids (mg/dl) } & \multicolumn{5}{|c|}{ Experimental groups } \\
\hline & NC & TC & ST & ET1 & ET2 \\
\hline $\mathrm{TL}$ & $287.1 \pm 7.5 a$ & $373.1 \pm 1.8 b$ & $300.7 \pm 8.4 a$ & $354.1 \pm 7.7 c$ & $314.6 \pm 6.08 a$ \\
\hline Cholesterol & $93.83 \pm 4.9 \mathrm{a}$ & $166.5 \pm 10.4 b$ & $103.8 \pm 4.0 \mathrm{a}$ & $135.8 \pm 1.8 c$ & $110.4 \pm 7.5 a$ \\
\hline HDL & $27.05 \pm 1.2 \mathrm{a}$ & $19.13 \pm 0.7 b$ & $25.26 \pm 1.3 a$ & $21.23 \pm 0.8 c$ & $24.50 \pm 0.7 \mathrm{ac}$ \\
\hline LDL & $42.74 \pm 2.0 a$ & $72.62 \pm 2.8 b$ & $46.52 \pm 1.0 a$ & $62.85 \pm 3.42 c$ & $47.93 \pm 1.81 a$ \\
\hline VLDL & $22.62 \pm 1.0 a$ & $48.11 \pm 2.9 b$ & $25.38 \pm 0.7 a$ & $30.86 \pm 0.9 c$ & $26.00 \pm 1.5 a$ \\
\hline TG & $68.20 \pm 1.5 a$ & $85.28 \pm 3.6 b$ & $72.06 \pm 2.3 a$ & $78.04 \pm 2.5 c$ & $70.11 \pm 1.9 a$ \\
\hline
\end{tabular}

NC = Normal Control; TC = Toxic Control; ST = Silymarine Control; ET1 = Extract (ZOX-LME) 200 mg/kg BW; ET2 = Extract (ZOX-LME) 400 mg/kg BW. Same alphabets in a row shows no significant difference $(P<0.05)$ while the different alphabets in the same row show significant difference $(P<0.05)$ among the mean of the parameters. 
$\mathrm{kg}$ BW) administered rabbits. Since it is clear that that (ZOX-LME) treatment is dose dependent i.e. high dose seems to be better in the recovery of hepatic and renal injury when compared with the results of toxic control animals that received $\mathrm{CCl}_{4}$ alone confirmed the healing effects of (ZOX-LME).

\subsection{Histological examinations}

Photomicrographs taken from liver and kidney sections of all experimental animals and were shown in Figure 1 (A1, A2, A3, A4 and A5) and Figure 2 (B1, B2, B3, B4, B4 and B5) respectively. Liver sections from control rabbit showed normal hepatic cells with well-preserved cytoplasm, prominent nucleus, nucleolus, central vein and compact arrangement of hepatocytes (Figure 1A1). In contrast to this, $\mathrm{CCl}_{4}$ caused hydropic alteration and necrosis in centrilobular hepatocytes (Figure 1A2). Sinusoids and central vein Congestion clarified acute inflammatory cells infiltrating. In animals treated with silymarin, showed histoarchitecture with mild infiltration of inflamed cells (Figure 1A3). Animals treatment with (ZOX-LME) at dose of $200 \mathrm{mg} / \mathrm{kg} \mathrm{BW}$, sinusoids and central vein congestion and acute inflammatory cells infiltrating were of less extent (Figure 1A4). No tissue damage and necrosis was observed at hepatocyte cords in the liver of (ZOX-LME) ingestion at dose rate $400 \mathrm{mg} / \mathrm{kg} \mathrm{BW}$ (Figure 1A5). In the Figure 2B1, B2, B3, B4 and B5, the kidney sections of the different groups have been shown. In Figure 2B1, there was normal lung having no lesions as compared to the normal control group. The group that was infected but not medicated (Figure 2B2) had tissue damage and necrosis with cellular congestion. The silymarine medicated group (Figure 2B3) had a normal kidney appearance. Kidney section of animals treated with $200 \mathrm{mg} / \mathrm{kg}$ BW of (ZOX-LME) has acute inflammatory cells infiltrating were and mild haemomoraghic status (Figure 1A4). Normal histoarchitecture with mild inflammation was seen in the kidney of animals ingested (ZOX-LME) at dose rate $400 \mathrm{mg} / \mathrm{kg}$ BW (Figure 1A5). The scoring of histological damage is displayed in Table 5.

\subsection{DPPH activity}

The results for antioxidant activity against DPPH of (ZOX-LME) at various concentrations are shown in Table 6. The percent inhibition values were $32.66 \%, 51.96 \%, 59.71 \%$, $67.70 \%$ and $81.55 \%$ respectively. Various concentrations of

Table 4. Shows serum antioxidant enzyme activities $(\mathrm{M} \pm \mathrm{SD})$ of the experimental animal groups treated with $\mathrm{CCl}_{4}$, silymarine and (ZOX-LME), extract.

\begin{tabular}{cccccc}
\hline \multirow{2}{*}{ Antioxidant biomarkers } & \multicolumn{5}{c}{ Experimental groups } \\
\cline { 2 - 6 } & NC & TC & ST & ET2 & ET1 \\
\hline TBARS U/mL & $3.5 \pm 0.2 \mathrm{a}$ & $5.2 \pm 0.6 \mathrm{~b}$ & $3.4 \pm 0.3 \mathrm{a}$ & $4.6 \pm 0.3 \mathrm{bc}$ & $4.3 \pm 0.4 \mathrm{a}$ \\
GSH U/mL & $0.22 \pm 0.01 \mathrm{a}$ & $0.16 \pm 0.01 \mathrm{~b}$ & $0.21 \pm 0.00 \mathrm{a}$ & $0.17 \pm 0.00 \mathrm{~b}$ & $0.20 \pm 0.01 \mathrm{a}$ \\
GST U/mL & $0.84 \pm 0.01 \mathrm{a}$ & $0.72 \pm 0.02 \mathrm{~b}$ & $0.83 \pm 0.01 \mathrm{a}$ & $0.75 \pm 0.02 \mathrm{~b}$ & $0.82 \pm 0.00 \mathrm{a}$ \\
CAT U/mL & $0.96 \pm 0.02 \mathrm{a}$ & $0.67 \pm 0.01 \mathrm{~b}$ & $0.90 \pm 0.01 \mathrm{a}$ & $0.73 \pm .06 \mathrm{bc}$ & $0.88 \pm 0.03 \mathrm{a}$ \\
\hline
\end{tabular}

NC = Normal Control; TC = Toxic Control; ST = Silymarine Control; ET1 = Extract (ZOX-LME) 200 mg/kg BW; ET2 = Extract (ZOX-LME) 400 mg/kg BW. Same alphabets in a row shows no significant difference $(\mathrm{P}<0.05)$ while the different alphabets in the same row show significant difference $(\mathrm{P}<0.05)$ among the mean of the parameters.
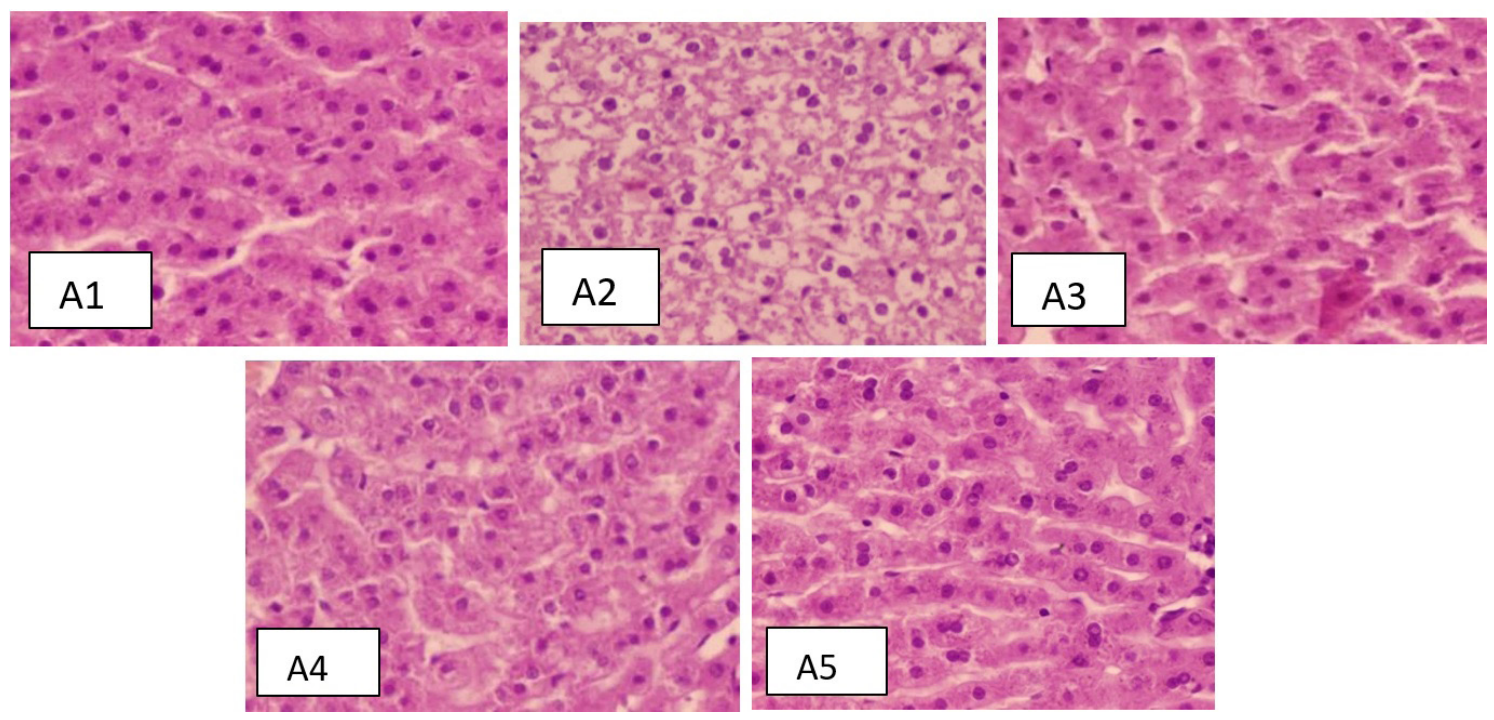

Figure 1. Photomicrographs of liver section from various experimental animal groups (A1, A2, A3, A4, and A5). 
(ZOX-LME) showed percent inhibition in the following order $20 \mathrm{ppm}<60 \mathrm{ppm}<80 \mathrm{ppm}<100 \mathrm{ppm}<200 \mathrm{ppm}$. The increased in extract concentration caused an increase in percent inhibition showed the antioxidant potential of (ZOX-LME) (Table 6).

\section{Discussion}

Liver damage is a major health problem and is a serious challenge to public health in the world (Pimpin et al., 2018). The existing synthetic liver treatment drugs create

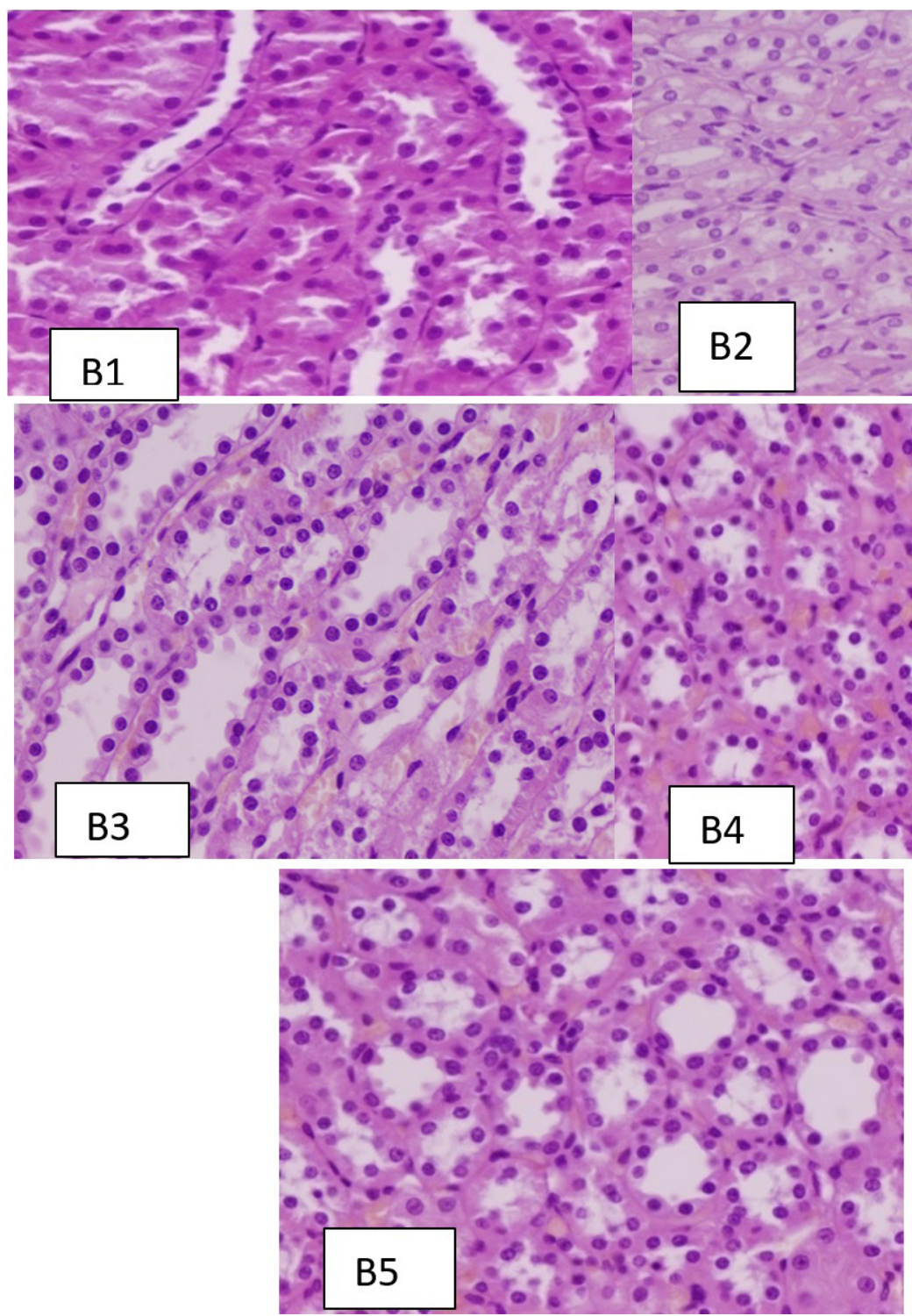

Figure 2. Photomicrographs of kidney section from various experimental animal groups (B1, B2, B3, B4 and B5).

Table 5. Semiquantitive score of histopathological findings.

\begin{tabular}{ccccc}
\hline Groups & Hydropic degeneration & Liver steatosis & Inflammatory cell infiltration & Necrosis \\
\hline Group A & 0 & 0 & 0 & 0 \\
Group B & +++ & ++ & +++ & +++ \\
Group C & + & 0 & 0 & + \\
Group D & ++ & 0 & + & + \\
Group E & + & 0 & 0 & + \\
\hline
\end{tabular}

Damage grade are as follow: 0 = no abnormality; + = mild injury; ++ = moderate injury and +++ = severe injury. 
Table 6. Shows radical scavenging activity of (ZOX-LME), extract concentrations on the basis of percent inhibition of DPPH free radicals.

\begin{tabular}{ccc}
\hline $\begin{array}{c}\text { (ZOX-LME) } \\
\text { extract Conc }\end{array}$ & \% Inhibition & Mean \pm SEM \\
\hline $20 \mathrm{ppm}$ & $32.66 \%$ & $26.70 \pm 4.38$ \\
$60 \mathrm{ppm}$ & $51.96 \%$ & $48.70 \pm 3.49$ \\
$80 \mathrm{ppm}$ & $59.71 \%$ & $54.70 \pm 4.20$ \\
$100 \mathrm{ppm}$ & $67.70 \%$ & $62.76 \pm 1.21$ \\
$200 \mathrm{ppm}$ & $81.55 \%$ & $71.7 \pm 0.89$ \\
\hline
\end{tabular}

further complications hence; herbal medicines have more demands and widespread use in hepatic disorders since long time (Rotman and Sanyal, 2017). The current study intended to reveals the hepato and renal protective and antioxidant effects of (ZOX-LME) against $\mathrm{CCl}_{4}$-induced toxicity in rabbits. For the screening of hepatoprotective drugs, frequently $\mathrm{CCl}_{4}$ is used as hepatotoxic agent in the laboratories. $\mathrm{CCl}_{4}$ is break down to the trimethyl radical $(\mathrm{CCl} 3)$ and a proxy trichlomethyl radical $(\mathrm{OOCCl} 3)$ by cytochrome P-450 2EI enzyme (Jia et al., 2011), these radicals bind covalently to the macromolecules and probably caused lipid peroxidation by attacking membrane polyunsaturated fatty acids, there by disturbing membrane integrity and caused hepatic damage associated with oxidative stress (Dahiru et al., 2013). Liver damage is evaluated by assessing the concentration of discharged transaminases including ALT, AST and ALP in blood (van Deursen et al., 2014)

Results of the present study revealed increased in serum ALT, AST, ALP and RBCs, WBCs, platelets and haemoglobin levels in carbon tetra chloride $\left(\mathrm{CCl}_{4}\right)$ administered rabbits when compared with normal control rabbits $(\mathrm{P}<0.05)$.Immediate rise in serum transaminases showed, $\mathrm{CCl}_{4}$ induced severe toxicity (Jannu et al., 2012). The statement was confirmed by necrosis and infiltration of inflammatory cells during histopathological examination of microphotographs of liver sections (Jiang et al., 2016), reported that several pharmaceutical drugs like rifampicin, isoniazid, paracetamol, etc. are used in medical therapy are hepatotoxic, producing free-radical that causes lipid membrane peroxidation resulting hepatocytes injury.

During the present research the rabbits intoxicated with carbon tetrachloride $\left(\mathrm{CCl}_{4}\right)$ were treated with a standard antioxidant drug, Silymarine and (ZOX-LME) of graded doses. Silymarine is a standard antioxidant drug and frequently used as a hepatoprotective medicine, derived from a plant, Silybum marianum (Tajmohammadi et al., 2018). In this study administration of (ZOX-LME) at dose $400 \mathrm{mg} / \mathrm{kg} \mathrm{BW}$ to $\mathrm{CCl}_{4}$ intoxicated rabbits reduced the elevated level of ALT, AST, ALP and blood factors toward normal. These results are nearly equivalent to the standard drug, Silymarine. The current study is in agreement with that of (Cordeiro and Kaliwal, 2013), who investigated the liver protective activity of the alcohol extract of Capparis sepiaria stem against $\mathrm{CCl}_{4}$ intoxicated Albino rats. The kidney is a major homeostatic organ keeps the balance of body fluids by cleaning and secreting metabolites like urea, uric acid, creatinine, and minerals from the blood and eliminate the nitrogenous wastes together with water, as urine (Javaid et al., 2012). It retains the overall intracellular chemical composition by regulating the concentration of water, sodium chloride, potassium, phosphate and many other elements in the body.

An increase in creatinine, urea, uric acid and blood urea nitrogen along with serum ions concentrations ( $\mathrm{Ca}$, $\mathrm{Mg}, \mathrm{Cl}, \mathrm{Na}, \mathrm{K}$, and $\mathrm{P}$ ) indicated a kidney dysfunction in a $\mathrm{CCl}_{4}$ administered animals. However high dose of (ZOXLME) feeding showed significant $(\mathrm{P}>0.05)$ normalizing effects. These finding are in agreement with previous studies (El Saied Azab et al., 2014) who demonstrated the nephro-preventive role of rosemary, curcumin and propolis against gentamicin induced toxicity in guinea pigs. Related findings were presented by (Muhammad et al., 2015), who investigate the effects of Vitex doniana aqueous bark extract on serum electrolytes levels in Albino rats. In a condition like hepatic or renal injury make the lipid profile disrupted. As evident from our study in which $\mathrm{CCl}_{4}$ ingestion caused significant increase in total lipid (TL), cholesterol, LDL, VLDL and TG level and decrease HDL value. Moreover, administration of (ZOX-LME) extract regulated the serum lipid markers toward normal level. This is in agreement with (El-Baz et al., 2015), who investigate the effectiveness of sesame oil as antihypercholesterolemic substance in rats fed rich-fat diet.

In addition, carbon tetrachloride $\mathrm{CCl}_{4}$ caused cellular toxicity and necrosis by reducing the efficiency of serum antioxidant enzymes i.e., catalase (CAT), glutathione peroxidase (GSH), glutathione (GST) and enhanced the production of TBARS (Alam, 2018). The cellular endogenous defense system consist of enzymatic and non-enzymatic antioxidants such as SOD, CAT, GSH and GST which controlled the oxidative stress generated as a result of tissues damage. In present study, the level of catalase (CAT), glutathione peroxidase (GSH), glutathione (GST), were significantly $(\mathrm{P}>0.05)$ lowered in $\mathrm{CCl}_{4}$ administered animals when compared to the control animals.

Treatment of rabbits with either (ZOX-LME) or silymarin ameliorated the toxic effects of $\mathrm{CCl}_{4}$ and restored the levels of serum CAT, GSH, GST towards the control group in accordance with other findings (using Oxalis corniculata whole plant extract against carbon tetrachloride, toxicity in rats. They find a significant ameliorative effect on serum glutathione GSH, GST and CAT contents in rat. Similar findings were also presented by (Adesanoye and Farombi, 2010), who investigated the hepatoprotective effects of Vernonia amygdalina in carbon tetrachloride intoxicated rats. Investigative of TBARS serves as an indirect marker of lipid peroxidation of polyunsaturated fatty acids of hepatocyte membrane (Zargari and Sedighi, 2015). Rise in TBARS level by $\mathrm{CCl}_{4}$ ingestion in this study shows the liver injury including series of chain reactions. Results of this study revealed that (ZOX-LME) ingestion at high dose reduced the TBARS levels toward normal value. This decreased in TBARS level may be due to active ingredients of (ZOX-LME) extract that may responsible for scavenging ROS and improving the antioxidant potentials of tissues. Our study is in agreement with (Quan et al., 2013), studied 
the hepatoprotective of polysaccharides extracted from Boschniakia rossica, actin against carbon tetrachlorideinduced toxicity in mice.

The antioxidant capacity of (ZOX-LME) was assessed through the DPPH radical scavenging assay. The present results showed that (ZOX-LME) exhibit good percent scavenging radical inhibition value even at lowest concentration and an increased was noted with increasing concentration of (ZOX-LME). The antioxidant activity of (ZOX-LME) may be due to their redox properties, which allow them to act as reducing agents, hydrogen donators, and singlet oxygen quenchers and some of the pharmacological effects might be due to these valuable compounds. These results are in accordance with findings of Jothy et al. (2011) and Enujiugha et al. (2012), whom explored African Sphenostylis stenocarpa phenolic extracts and Cassia fistula seeds extract for its scavenging capacity on the basis of DPPH radical scavenging assay.

The liver and kidney sections of rabbits treated with (ZOX-LME) after $\mathrm{CCl}_{4}$ intoxication are revealed to have amended cellular membrane architecture or less damage to the hepatic cells as compared to rabbits treated with $\mathrm{CCl}_{4}$. The improved histoarchitecture further verify the liver preventive potential of the (ZOX-LME) and support the results of biochemical parameters. Normalization of $\mathrm{CCl}_{4}$ impaired liver and kidney architecture by therapeutic plants were described by many investigators like Nwaigwe et al. (2012) reported the regulation of hepatotoxicity by Olax viridis, Tephrosia calophylla and Curcuma longa respectively.

Finally it is evident from overall results and discussion that (ZOX-LME) ingestion can mitigate all the adverse effects of $\mathrm{CCl}_{4}$ on liver transaminases, hematological indices, renal function biomarkers along with serum ion concentrations and the lipid profile by the virtue of its vital ingredients . In addition, the decreased level of (TBARS) and elevated activity of GSH, GST and CAT in $\mathrm{CCl}_{4}$ intoxicated animals after giving (ZOX-LME) indicated that lipid peroxidation was inhibited. The effect of (ZOX-LME) similar to the effect of silymarine in comparison with toxic control animals. This action could be attributed to the high content of phytochemical constituents which are potent antioxidants can protect liver and kidney cells from injury. Zizyphus oxyphyla contain alkaloids, flavonoids and saponins and other active phytochemicals (Kaleem et al., 2014).

\section{Conclusion}

From the present study it was concluded that the (ZOX-LME) extract is very potent against liver and kidney damage. The (ZOX-LME) extract is also beneficial for most of hematological and lipid parameters. In addition, (ZOXLME) extract has potent antioxidant capacity revealed form good healing ability by improving and regulating the impaired levels of serum glutathione GSH and GST and catalases CAT (cellular antioxidants). Therefore one can use this plant extract (ZOX-LME) traditionally, for many liver disorders. Further this plant extract can also be used scientifically for other fatal and chronic diseases. Hence this research recommends that the (ZOX-LME) possess the anti-oxidant property, which could be used as best source of advance medication. Thus further exploration of the plant is required.

\section{Acknowledgements}

The authors would like to acknowledge and to thank the Taif University Researchers Supporting Project number (TURSP-2020/71), Taif University, Taif, Saudi Arabia.

\section{References}

ABDEL-MONEIM, A.M., AL-KAHTANI, M.A., EL-KERSH, M.A. and ALOMAIR, M.A., 2015. Free radical-scavenging, anti-inflammatory/ anti-fibrotic and hepatoprotective actions of taurine and silymarin against $\mathrm{CCl} 4$ induced rat liver damage. PLoS One, vol. 10, no. 12, e0144509. http://dx.doi.org/10.1371/journal. pone.0144509. PMid:26659465.

ADEGOKE, O., CHIDAWANYIKA, W. and NYOKONG, T., 2012. Interaction of CdTe quantum dots with 2, 2-diphenyl-1picrylhydrazyl free radical: a spectroscopic, fluorimetric and kinetic study. Journal of Fluorescence, vol. 22, no. 2, pp. 771-778. http://dx.doi.org/10.1007/s10895-011-1012-2. PMid:22051981.

ADESANOYE, O.A. and FAROMBI, E.O., 2010. Hepatoprotective effects of Vernonia amygdalina (astereaceae) in rats treated with carbon tetrachloride. Experimental and Toxicologic Pathology, vol. 62, no. 2, pp. 197-206. http://dx.doi.org/10.1016/j.etp.2009.05.008. PMid:19581077.

ALAM, M.F., 2018. Neuroprotective effects of Zingerone against carbon tetrachloride $\left(\mathrm{CCl}_{4}\right)$ induced brain mitochondrial toxicity in Swiss albino mice. Journal of Applied and Natural Science, vol. 10, no. 2, pp. 548-552. http://dx.doi.org/10.31018/ jans.v10i2.1734.

BJÖRNSSON, E.S., 2016. Hepatotoxicity by drugs: the most common implicated agents. International Journal of Molecular Sciences, vol. 17, no. 2, pp. 224. http://dx.doi.org/10.3390/ijms17020224. PMid:26861310.

CONTRERAS-ZENTELLA, M.L. and HERNÁNDEZ-MUÑOZ, R., 2016. Is liver enzyme release really associated with cell necrosis induced by oxidant stress? Oxidative Medicine and Cellular Longevity, vol. 2016, pp. 3529149. http://dx.doi.org/10.1155/2016/3529149. PMid:26798419.

CORDEIRO, M. and KALIWAL, B., 2013. Protective role of bark extract of Bridelia retusa Spreng on $\mathrm{CCl}_{4}$ induced histological toxicity in mice. Journal of Pharmacognosy and Phytochemistry, vol. 2, no. 4, pp. 142-148.

DAHIRU, D., AMOS, A. and SAMBO, S.H., 2013. Effect of ethanol extract of Calotropis procera root bark on carbon tetrachlorideinduced hepatonephrotoxicity in female rats. Jordan Journal of Biological Sciences, vol. 147, no. 898, pp. 1-4. http://dx.doi. org/10.12816/0001538.

DANLADI, J., ABDULSALAM, A., TIMBUAK, J., AHMED, S., MAIRIGA, A. and DAHIRU, A., 2013. Hepatoprotective effect of black seed (Nigella sativa) oil on carbon tetrachloride $\left(\mathrm{CCL}_{4}\right)$ induced liver toxicity in adult wistar rats. Journal of Dental and Medical Sciences, vol. 4, no. 3, pp. 56-62. http://dx.doi.org/10.9790/0853-0435662.

ELSAIED AZAB, A., FETOUH, F.A. and ALBASHA, M.O., 2014. Nephroprotective effects of curcumin, rosemary and propolis against gentamicin induced toxicity in guinea pigs: morphological and biochemical study. American Journal of Clinical and Experimental Medicine, vol. 2, no. 2, pp. 28-35. http://dx.doi.org/10.11648/j. ajcem.20140202.14. 
EL-BAZ, F.K., SALAMA, Z.A., ALY, H.F. and TAIE, H.A., 2015. Potency of sesame oil as antihypercholesterolemic agent in rats fed high-fat diet. Experimental Animals, vol. 20, pp. 21.

EL-HASKOURY, R., AL-WAILI, N., KAMOUN, Z., MAKNI, M., AL-WAILI, H. and LYOUSSI, B., 2018. Antioxidant activity and protective effect of carob honey in $\mathrm{CCl}_{4}$-induced kidney and liver injury. Archives of Medical Research, vol. 49, no. 5, pp. 306-313. http:// dx.doi.org/10.1016/j.arcmed.2018.09.011. PMid:30342848.

ENUJIUGHA, V., TALABI, J., MALOMO, S. and OLAGUNJU, A., 2012. DPPH radical scavenging capacity of phenolic extracts from African yam bean (Sphenostylis stenocarpa). Food and Nutrition Sciences, vol. 3, no. 1, pp. 7-13. http://dx.doi.org/10.4236/ fns.2012.31002.

FRENZEL, C. and TESCHKE, R., 2016. Herbal hepatotoxicity: clinical characteristics and listing compilation. International Journal of Molecular Sciences, vol. 17, no. 5, pp. 588. http://dx.doi. org/10.3390/ijms17050588. PMid:27128912.

GRIFFIN, G. and LOCKE, P., 2016. Comparison of the Canadian and US laws, regulations, policies, and systems of oversight for animals in research. ILAR Journal, vol. 57, no. 3, pp. 271-284. http://dx.doi.org/10.1093/ilar/ilw037. PMid:29117406.

IJAZ, F., IQBAL, Z., RAHMAN, I.U., ALAM, J., KHAN, S.M., SHAH, G.M., KHAN, K. and AFZAL, A., 2016. Investigation of traditional medicinal floral knowledge of Sarban Hills, Abbottabad, KP, Pakistan. Journal of Ethnopharmacology, vol. 179, pp. 208-233. http://dx.doi.org/10.1016/j.jep.2015.12.050. PMid:26739924.

JANNU, V., BADDAM, P.G., BOORGULA, A.K. and JAMBULA, S.R., 2012. A review on hepatoprotective plants. International Journal of Drug Development \& Research, vol. 4, no. 3, pp. 1-8.

JAVAID, R., ASLAM, M., NIZAMI, Q. and JAVAID, R., 2012. Role of antioxidant herbal drugs in renal disorders: an overview. Free Radicals and Antioxidants, vol. 2, no. 2, pp. 2-5. http://dx.doi. org/10.5530/ax.2012.2.2.

JIA, X.-Y., ZHANG, Q.-A., ZHANG, Z.-Q., WANG, Y., YUAN, J.-F., WANG, H.-Y. and ZHAO, D., 2011. Hepatoprotective effects of almond oil against carbon tetrachloride induced liver injury in rats. Food Chemistry, vol. 125, no. 2, pp. 673-678. http://dx.doi. org/10.1016/j.foodchem.2010.09.062.

JIANG, W., GUO, M.-H. and HAI, X., 2016. Hepatoprotective and antioxidant effects of lycopene on non-alcoholic fatty liver disease in rat. World Journal of Gastroenterology, vol. 22, no. 46, pp. 10180-10188. http://dx.doi.org/10.3748/wjg.v22.i46.10180. PMid:28028366.

JOTHY, S.L., ZURAINI, Z. and SASIDHARAN, S., 2011. Phytochemicals screening, DPPH free radical scavenging and xanthine oxidase inhibitiory activities of Cassia fistula seeds extract. Journal of Medicinal Plants Research, vol. 5, no. 10, pp. 1941-1947.

KALEEM, W.A., 2011. Molecular profiling of bioactive constituents from Zizyphus oxyphylla EDGEW. Peshawar: University of Peshawar.

KALEEM, W.A., MUHAMMAD, N., KHAN, H. and RAUF, A., 2014. Pharmacological and phytochemical studies of genus Zizyphus. Middle East Journal of Scientific Research, vol. 21, no. 8, pp. 1243-1263.

KAMAL, R., DAHIYA, P. and PURI, A., 2012. Oral pyogenic granuloma: various concepts of etiopathogenesis. Journal of Oral and Maxillofacial Pathology, vol. 16, no. 1, pp. 79-82. http://dx.doi. org/10.4103/0973-029X.92978. PMid:22434943.

KOKSAL, E., BURSAL, E., DIKICI, E., TOZOGLU, F. and GULCIN, I., 2011. Antioxidant activity of Melissa officinalis leaves. Journal of Medicinal Plants Research, vol. 5, no. 2, pp. 217-222.

LEAMKLANG, W., 2018. Antioxidant activities of bioactive compounds from Barrington augusta Kurz. and Syzygium gratum (Wight) S.N. Mitra var. gratum in Ban Ang-Ed Official Community Forest Project
(The Chaipattana Foundation). Thailand: Burapha University, 115 p. Thesis in Biological Science.

LUCKNER, M., 2013. Secondary metabolism in microorganisms, plants and animals. Berlin: Springer Science and Business Media.

MAHMOODZADEH, Y., MAZANI, M. and REZAGHOLIZADEH, L., 2017. Hepatoprotective effect of methanolic Tanacetum parthenium extract on $\mathrm{CCl}_{4}$-induced liver damage in rats. Toxicology Reports, vol. 4, pp. 455-462. http://dx.doi.org/10.1016/j. toxrep.2017.08.003. PMid:28959674.

MITRAKOU, A., 2011. Kidney: its impact on glucose homeostasis and hormonal regulation. Diabetes Research and Clinical Practice, vol. 93, suppl. 1, pp. S66-S72. http://dx.doi.org/10.1016/S01688227(11)70016-X. PMid:21864754.

MUHAMMAD, A., WUDIL, A., YUNUSA, I., MUKHTAR, Z., SHARIF, A. and KABARA, H., 2015. Oral administration of aqueous bark extract of Vitex doniana affects serum electrolytes levels in Albino rats. Point Journal of Medical Research, vol. 1, no. 1, pp. 1-5.

NWAIGWE, C., MADUBUNYI, I., UDEM, S. and NWAIGWE, C., 2012. Methanolic root extract of Olax viridis protects the liver against acetaminophen-induced liver damage. Research Journal of Medicinal Plant, vol. 6, no. 5, pp. 395-405. http://dx.doi. org/10.3923/rjmp.2012.395.405.

OLANIYAN, M.F. and ATENI, O., 2018. Changes in plasma alanine transaminase/serum glutamic-pyruvic transaminase, aspartate transaminase/serum glutamic-oxaloacetic transaminase, glutathione transferase, and albumin in rabbits given amoxicillin overdose supplemented with cucumber fruit juice. Imam Journal of Applied Sciences, vol. 3, no. 1, pp. 22.

OLIBONI, L.S., DANI, C., FUNCHAL, C., HENRIQUES, J.A. and SALVADOR, M., 2011. Hepatoprotective, cardioprotective, and renal-protective effects of organic and conventional grapevine leaf extracts (Vitis labrusca var. Bordo) on Wistar rat tissues. Anais da Academia Brasileira de Ciências, vol. 83, no. 4, pp. 14031411. http://dx.doi.org/10.1590/S0001-37652011000400027. PMid:22146965.

ORGANISATIONFORECONOMICCO-OPERATION ANDDEVELOPMENT - OECD, 2001. Policies to enhance sustainable development. Paris: OECD.

PIMPIN, L., CORTEZ-PINTO, H., NEGRO, F., CORBOULD, E., LAZARUS, J.V., WEBBER, L., SHERON, N. and COMMITTEE, E.H.S., 2018. Burden of liver disease in Europe: epidemiology and analysis of risk factors to identify prevention policies. Journal of Hepatology, vol. 69, no. 3, pp. 718-735. http://dx.doi.org/10.1016/j. jhep.2018.05.011. PMid:29777749.

QUAN, J., LI, T., ZHAO, W., XU, H., QIU, D. and YIN, X., 2013. Hepatoprotective effect of polysaccharides from Boschniakia rossica on carbon tetrachloride-induced toxicity in mice. Journal of Clinical Biochemistry and Nutrition, vol. 52, no. 3, pp. 12-96. http://dx.doi.org/10.3164/jcbn.12-96. PMid:23704815.

ROTMAN, Y. and SANYAL, A.J., 2017. Current and upcoming pharmacotherapy for non-alcoholic fatty liver disease. Gut, vol. 66, no. 1, pp. 180-190. http://dx.doi.org/10.1136/ gutjnl-2016-312431. PMid:27646933.

RUBBIA-BRANDT, L., LAUWERS, G.Y., WANG, H., MAJNO, P.E., TANABE, K., X ZHU, A., BREZAULT, C., SOUBRANE, O., ABDALLA, E.K., VAUTHEY, J.-N., MENTHA, G. and TERRIS, B., 2010. Sinusoidal obstruction syndrome and nodular regenerative hyperplasia are frequent oxaliplatin-associated liver lesions and partially prevented by bevacizumab in patients with hepatic colorectal metastasis. Histopathology, vol. 56, no. 4, pp. 430-439. http:// dx.doi.org/10.1111/j.1365-2559.2010.03511.x. PMid:20459550.

SHARIFI-RAD, M., FOKOU, P.V.T., SHAROPOV, F., MARTORELL, M., ADEMILUYI, A.O., RAJKOVIC, J., SALEHI, B., MARTINS, N., IRITI, 
M. and SHARIFI-RAD, J., 2018. Antiulcer agents: from plant extracts to phytochemicals in healing promotion. Molecules (Basel, Switzerland), vol. 23, no. 7, pp. 1751. http://dx.doi. org/10.3390/molecules23071751. PMid:30018251.

TAJMOHAMMADI, A., RAZAVI, B.M. and HOSSEINZADEH, H., 2018. Silybum marianum (milk thistle) and its main constituent, silymarin, as a potential therapeutic plant in metabolic syndrome: A review. Phytotherapy Research, vol. 32, no. 10, pp. 1933-1949. http://dx.doi.org/10.1002/ptr.6153. PMid:30015401.

TAN, H., HE, Q., LI, R., LEI, F. and LEI, X., 2016. Trillin reduces liver chronic inflammation and fibrosis in carbon tetrachloride $\left(\mathrm{CCl}_{4}\right)$ induced liver injury in mice. Immunological Investigations, vol. 45, no. 5, pp. 371-382. http://dx.doi.org/10.3109/08820139.20 15.1137935. PMid:27219527.

VAN DEURSEN, V.M., EDWARDS, C., COTTER, G., DAVISON, B.A., DAMMAN, K., TEERLINK, J.R., METRA, M., FELKER, G.M., PONIKOWSKI, P., UNEMORI, E., SEVERIN, T. and VOORS, A.A., 2014. Liver function, in-hospital, and post-discharge clinical outcome in patients with acute heart failure: results from the relaxin for the treatment of patients with acute heart failure study. Journal of Cardiac Failure, vol. 20, no. 6, pp. 407-413. http:// dx.doi.org/10.1016/j.cardfail.2014.03.003. PMid:24642379.

WANG, D.-W., YIN, Y.-M. and YAO, Y.-M., 2013. Advances in the management of acute liver failure. World Journal of Gastroenterology, vol. 19, no. 41, pp. 7069-7077. http://dx.doi. org/10.3748/wjg.v19.i41.7069. PMid:24222950.

YAN, J., LI, S. and LI, S., 2014. The role of the liver in sepsis. International Reviews of Immunology, vol. 33, no. 6, pp. 498-510. http://dx.doi.org/10.3109/08830185.2014.889129. PMid:24611785.

ZARGARI, M. and SEDIGHI, O., 2015. Influence of hemodialysis on lipid peroxidation, enzymatic and non-enzymatic antioxidant capacity in chronic renal failure patients. Nephro-Urology Monthly, vol. 7, no. 4, e28526. http://dx.doi.org/10.5812/ numonthly.28526. PMid:26539417. 